\title{
Analysis of the Construction and Development of Regional Library Consortia
}

\author{
Rui Wang \\ Nanyang Institute of Technology, Henan, Nanyang, 473000
}

Keywords: Regional Library Alliance; Problem Analysis; Development Strategy

\begin{abstract}
The regional library consortia, namely, the regional library consortium, refer to the library consortium jointly established by libraries in a certain region. It belongs to a type of information resource sharing system and its main purpose is to improve the regional informatization to meet the information needs in the development of the regional economy, culture and education, and to realize the co-construction and sharing of various documents and information resources through division of labor and cooperation. The "regional" in the regional library federation has no distinction between big and small. It is only a geographical concept and can theoretically be expanded indefinitely. Strengthening the construction of the regional library alliance undoubtedly can improve the utilization rate of library resources, enhance the basic functions of the library, to meet the reader's spiritual and cultural needs to the greatest extent. The article mainly discusses the construction and development of the regional library alliance.
\end{abstract}

\section{The Main Function of the Regional Library Union}

Specifically, the functions of the regional library consortium mainly include the following aspects:

Different regions of our country have their own local characteristics. The library should fully exploit the advantages of the local special literature resources and establish a distinctive collection of resources and special databases to provide services to readers in various forms. The development and application of the characteristic document resources are very beneficial to promote the regional economic development and establish the special library alliance. In some areas, due to resource constraints and security management, the number of public libraries is far less than the number of primary and secondary schools. Through the library alliance to carry out public reading services, it greatly improving the openness of the library, to better meet the urban public reading needs. Library Alliance to break the institutional barriers, and other enterprises and institutions to form a depth of cooperation and improve the openness of resources; For example, with the formation of alliances with business units, and enterprise technical personnel training highly integrated, the establishment of industry information service platform; or knowledge The combination of property management departments, the establishment of intellectual property training base to raise awareness of local people's intellectual property rights, to provide information services for the protection of property rights and so on.

\section{The Obstacles Affecting the Regional Library Alliance}

Although the cooperation among libraries in various regions is a general trend of library and information service, the following problems inevitably exist in the practical implementation:

Libraries in our country belong to public institutions. All along, business management systems have the problem of fragmentation and long management. Under the long-term management system, libraries are fragmented and lack the awareness of information resources co-construction and sharing, and can not enlarge the main information services Function, weakening the social function of the library. Difficulties in the cooperation between the libraries and difficulties in coordination led to the problem that the problem of lack of information resources caused by duplication and omission of documents during the repeated construction while there was a shortage of funds led to the problems of various libraries in the same area The unbalanced distribution of literature 
information resources has a direct impact on the service effectiveness of libraries and the utilization of information resources.

The LIB is a long-term and systematic project that is closely related to various libraries in the region. Although each librarian has realized the importance of document resources sharing, it is very difficult in practice. In order to realize the deep union of the libraries, we need efficient administrative measures and strengthened the construction of information technology and all kinds of infrastructures. However, in fact, due to the weak foundation and lack of funds of various libraries, many libraries have been restricted by their own conditions The traditional means of service led to imbalanced investment in professional skills and information services among libraries, which directly affected the development of the library alliance.

In the developed countries such as Britain, the United States, Japan and so on, from the national level to the basic library, every link has attached great importance to the construction and sharing of the document resources, promulgated various laws and regulations, and formed a complete set of resources Build a shared security system. At present, however, the legislation for library document resources sharing in our country is still blank. At present, only the policy documents formulated by the governments and administrative systems of all localities coordinate the document sharing activities, lacking the regulatory documents that can restrict the library and intelligence agencies, as a result, the sharing of document resources between libraries can not be followed and is unviable, which is extremely unfavorable to the development of library alliance.

\section{The Common Mode of Construction of Regional Library Alliance}

Alliance is a cooperative relationship formed among member units, which is not strictly controlled. Therefore, the library should choose the appropriate alliance mode based on its own actual conditions. Specifically, the construction of regional library alliance model and management model include the following:

The model of library alliance includes the central museum model, multi-storey museum model, parallel museum model and virtual center museum model. Among them, the central museum model consists of a strong library as the central museum and other member libraries of the library. The central responsibility of the central museum is to plan and coordinate the relationships among the member museums and to undertake the major Mission, member hall plays a supporting role. In some libraries is small, close to each other can use this model of organization. Multi-storey Museum is based on a central museum, and then set up one or several branch museums to share the center to develop policy planning, regulation and cooperation responsibilities, this model applies to a large number of regional libraries. There is no central hall in the side-by-side hall mode. Cooperation mechanisms are established through communication and coordination between each hall. Each hall determines the key points for the construction of the information resources of the library according to the resources of its own collections. This mode of organization is relatively simple but management is also relatively loose. The virtual center pavilion model, as its name implies, does not have an entity center pavilion, but it can establish agreements approved by member pavilions and control the total database of each pavilion in order to realize the co-construction and sharing of the literature resources in each pavilion.

Management models include council model, agreement model and build model. The council model refers to the establishment of an alliance leading decision-making body, that is, the coalition council, this model can break the system of fragmented administrative management system, the members of the Museum for coordination, communication, alliance encountered significant development process The questions are all discussed and decided by the coalition council. The council organization includes the chairman, vice president, director, etc; the union council further under the reference, interlibrary loan and document delivery, platform construction and maintenance, resource construction and personnel training and other professional groups. Agreement mode refers to the form of alliance between the members signed an agreement to establish alliances, members of the Museum of digital unified service platform as the core, the regional members of the Museum of the integration of the literature and information resources, 
members of the Museum of the reader direct access to the shared database that Can enjoy the information service. Because of the loose management, this model is suitable for the application and dissemination of the interlibrary literature resources in the virtual space. The co-construction model focuses on overall planning of the collection of document resources in libraries in the region in accordance with the concept of co-ordination and makes decentralized document resources form an organic whole through division of labor and cooperation, and each member hall provides services to each other. This type of cooperation requires a high degree of dedication to member associations and requires joint efforts to overcome such problems as funding and organization.

\section{The Development and Construction Strategy of the Regional Library Alliance}

The construction and development of specific regional library alliance can proceed from the following aspects:

Library Union must first solve the management system to improve the management of the building, which is to ensure the normal operation of the library union necessary conditions. Alliance management process, according to the development of the regional library alliance to develop a reasonable management methods, such as the development of resource sharing management system, the Union members of the Museum of resources sharing and co-construction of the mandatory provisions to ensure that all members of the Museum are regional The construction of information resources provides services to enable all users in the region to enjoy more abundant information resources services. In addition, the library union should also be regarded as a whole, in order to achieve the unified management of the entire union, to promote the implementation and implementation of the system, focusing on the improvement, revision, implementation and supervision of various rules and regulations; Collection layout of the co-ordination, coordination; the development of various services and performance evaluation; intellectual property protection and so on.

Depending on the size and capability of the member federations, the functions and responsibilities of each member hall should be clearly and rationally allocated to the rights and obligations of each member hall and their interests so as to complement each other's advantages and give full play to the economies of scale in the region, Reduce the overall cost of information products, and realize the low-cost and professional development of member libraries. If some member libraries have poor hardware conditions, the electronic data can be stored in the core server and the proxy server can be used to share the electronic resources with the electronic resources of other member libraries. In combination with the economic zone development plan, we will focus on the regional key layouts and carry out the collection, monitoring and analysis of related information, especially the analysis of patent information, conduct targeted intelligence research and decision-making consulting activities and ensure the scientific development of regional economy.

The specific measures for sharing services of regional library federations include document retrieval services such as joint catalogs, compact disc databases, self-built databases and online resource databases; interactive personalized services such as document booking, joint consultation, document delivery and interlibrary loan; task tracking , Personalized custom push service, information navigation and other online fixed service; and various types of service announcements, online user training services and so on. Of course, the alliance should strengthen its resources construction while focusing on and trying to integrate and link free resources in various national and regional resource sharing platforms such as the National Cultural Information Resource Sharing Project, the National Science and Technology Infrastructure Platform, National Science and Technology Library and Document Center, China University Humanities and Social Science Documentation Center. The integration, linkage and disclosure of various types of resource sharing platforms can expand the breadth of services.

\section{Conclusion}

In short, the library alliance is the main direction for the future development of the library. All 
the libraries through the alliance can enhance communication and coordination, and realize the resource sharing of the library, to meet the reader's information and information needs to the greatest extent. Joint procurement through library alliance, resource sharing, not only can enrich the region's information resources, but also can reduce the cost of library management and improve service effectiveness. Of course, at this stage, there still exist some problems such as loose management mechanism, unstable funding and not achieving complementary advantages among the member libraries. However, it is believed that these problems will be improved with the development of the library and information industry, and ultimately the realization of books Museum of sustainable development.

\section{References}

[1] Zheng Zhangfei. Research on the Development of Chinese Provincial University Library Alliance - A Case Study of Hunan University Digital Library [J]. The Work of University Libraries, 2017 (3): 36-39.

[2] Yan Xiufang. Current situation and countermeasures of the construction of regional library alliance in our country [J]. Library Theory and Practice, 2016 (6): 52-53

[3] Fan Yafang, Guo Taimin. Research on the Operational Mechanism of Regional League of Libraries in China [J]. Labor Service \& Research, 2015 (3): 259

[4] He Lin, Wu Lang. Status quo and development countermeasures of regional digital library alliance in China [J]. Journal of Library and Information Sciences, 2016 (12): 13-16.

[5] Xie Ling. Analysis of the Construction of Library Alliance in China from Washington Research Library Union in the United States [J]. Journal of Sichuan Library Science, 2017 (2): 63-67.

[6] Li Xiaojing, Fu Guizhen. A New Way to Get Out of the Dilemma of Collecting and Writing Non-GM Languages - The Significance of Establishing a League of Libraries in Foreign Language Universities and Colleges [J]. Journal Library Journal, 2017 (2): 15-18.

[7] Yan Jin-wei. Research on the Construction Model and Development Mechanism of Library Alliance [J]. Chinese Academic Journal, 2015,31 (4): 24-28. 